"Evaluation of R\&D activities in the maritime industry: Managing sustainability transitions through business model"

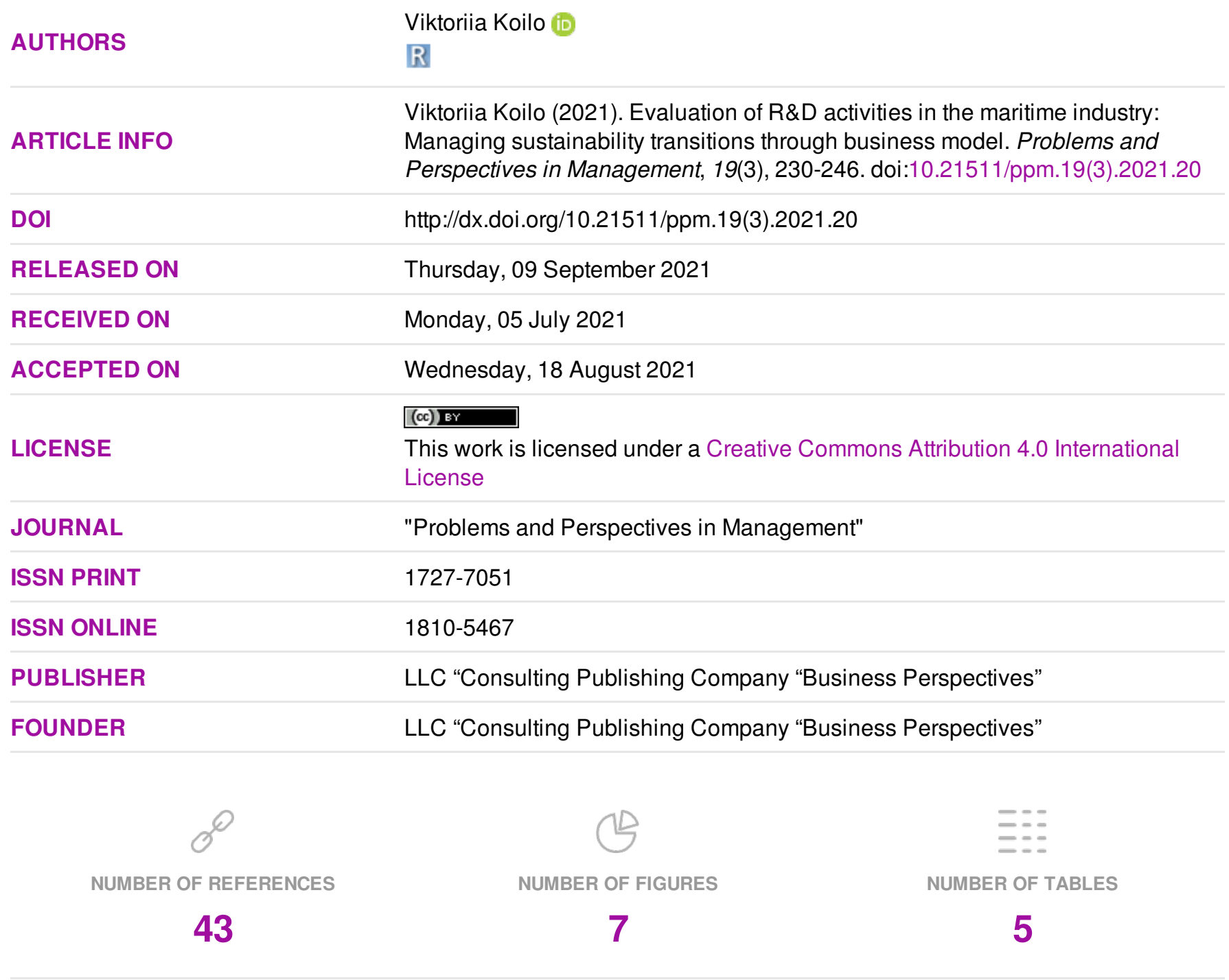

(c) The author(s) 2021. This publication is an open access article. 


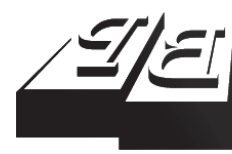

\section{BUSINESS PERSPECTIVES}

(O)

LLC "CPC "Business Perspectives" Hryhorii Skovoroda lane, 10, Sumy, 40022, Ukraine www.businessperspectives.org
Received on: $5^{\text {th }}$ of July, 2021 Accepted on: $18^{\text {th }}$ of August, 2021 Published on: $9^{\text {th }}$ of September, 2021

(C) Viktoriia Koilo, 2021

Viktoriia Koilo, Ph.D., Associate Professor, Department of Ocean Operations and Civil Engineering, Faculty of Engineering, Norwegian University of Science and Technology, Norway.

Viktoriia Koilo (Norway)

\title{
EVALUATION OF R\&D ACTIVITIES IN THE MARITIME INDUSTRY: MANAGING SUSTAINABILITY TRANSITIONS THROUGH BUSINESS MODEL
}

\begin{abstract}
The maritime industry is always at the forefront of knowledge and new technology. In recent years, the companies have used large resources in research and development (R\&D) towards environmentally friendly technology. At the same time, there exist many issues around this: are those companies enough good at the utilizing of R\&D fonds, i.e., do they put new technology together with solutions that are best adapted to the customer requirements (export-oriented), on the one hand, and are they efficient and sustainable, on another hand?
\end{abstract}

Hence, the current paper aims to study how the R\&D costs contribute to value creation and sustainable transition in the maritime industry. To achieve this goal, R\&D activities in the maritime industry were analyzed using correlation and linear regression analyses between 2010 and 2019 .

The results show that those indicators that have the greatest positive impact on valueadded are R\&D expenditures in the business enterprise sector and turnover from product innovations. Also, it was revealed that there is a negative impact of trade indicators on value creation. In addition, the study proves that $R \& D$ activities are contributing to the sustainable transition of the maritime industry.

Overall, it was concluded that without sufficient public support, strategy, and new business models, export-oriented industries benefit less from innovation.

Keywords

JEL Classification

\section{INTRODUCTION}

In a 2015 report, the European Cluster Observatory classified Blue Growth as one of Europe's key "emerging industries", corresponding to between 6-7\% of the European economy (OECD, 2016). The report found that Blue Growth industries had grown consistently faster than the overall economy. According to the 2014 ECORYS report on Blue Growth and Maritime Policy within the North Sea and Atlantic Sea Regions, Norway is the leading ocean economy in Europe in terms of Gross Value Added (GVA) and productivity (ECORYS, 2014). IHS/Menon Economics ranks Norway as the world's sixth-largest shipping fleet in terms of value being particularly strong on coastal, deep-sea, and offshore shipping.

Looking to 2030, many ocean-based industries have the potential to outperform the global economy, both in terms of value creation and employment. However, the ocean-based industries have so far lacked the political facilitation and funding infrastructure that has been granted to the land-based economy. 
Hence, research, knowledge, and technology development are crucial to unleash the potential for further value creation in the maritime industries and to ensure sustainable growth. The development of sustainable and emission-free solutions is crucial to meet the world's environmental challenges and increase the maritime industries' competitiveness in a global market. Digital solutions and new technology represent an important part of the restructuring and development of the maritime industries.

The ability to develop and use green ship technology will affect the opportunity to assert itself in the international market in the future, both for shipping companies, equipment suppliers, and the maritime industry in general.

In 2019, the Norwegian government presented a separate action plan for green shipping (Regjering, 2019). The action plan anchors the government's ambition to halve emissions from domestic shipping and fisheries by 2030. In addition, the government contributes money to large research and innovation projects with a green and sustainable purpose. In the Norwegian government's package of measures for green conversion, one billion kroner over three years was proposed for a new Green Platform. It is believed that innovation and new technology will help to adjust to a green future because the goal is to cut emissions while facilitating green growth. All green projects from research to market-ready solutions can apply for support under the Green Platform. Examples of relevant areas can be the circular economy, hydrogen and battery technology, and offshore wind, other renewable energy, bioeconomy, change in the supplier industry, as well as the marine sector.

At the same time, new technology solutions in the maritime industry are very promising, they should be created not only for the domestic market, but it should be export-oriented as well, and there are a few ways to make this happen: first - it would be best if the market is willing to pay for it; second - regulatory requirements from authorities; third - financial incentives from the authorities and the policy instruments.

European countries have developed for business comprehensive public policy instruments for R\&D. It is vitally important that they must be simplified and sharpened to achieve the political goals within climate and environment, business development, and renewable energy.

Due to greater breadth and scale in development courses aimed at environmentally friendly shipping by 2050, the maritime cluster organizations are doing valuable work in the green shift. These should be further stimulated and strengthened.

Nevertheless, there are already issues around this forced green transition in the industry. On one hand, the environmental consequences of economic growth and technical development have become an increasing concern (Grytten et al., 2020); on the other hand, companies are faced with a problem: there is often "a troubling gap between the inherent value of the technology they develop and their ability to put it to work effectively" (Leonard-Barton \& Kraus, 1985). Thus, there must be an increased focus on new strategies and new business models that will capture the value of the product.

All the above-mentioned proves the relevance of current investigation. Hence, the goal of the study is to investigate how such public policy instruments as $\mathrm{R} \& \mathrm{D}$ in the maritime industry can contribute to value creation; another point that should be analyzed is how innovation technology expenditures stand for the sustainable transition. 


\section{LITERATURE REVIEW}

In economic literature, one can find many scientists that consider R\&D and innovation activities as the same, and those two terms are often interchangeably used. Nevertheless, others will argue there is a significant difference between them: "innovation is differentiated from research and development $(\mathrm{R} \& \mathrm{D})$ by the fact that $\mathrm{R} \& \mathrm{D}$ transforms money into knowledge whereas innovation transforms knowledge into commercial opportunities" (Brussels, 2021).

A complementary understanding of innovation considers where and how the innovation is implemented. In the research literature, three levels are relevant (Gilje et al., 2018):

- Innovation within organizations (Management of innovation): here innovation is based on a given public organization and examines, for example, how organization and competence contribute to an innovative and dynamic organization. Examples of such organization-specific innovations could be the introduction of lean working methods or the development of new digital services for the municipality's residents.

- Innovation in a systems perspective (Systems of innovation): a systemic understanding of innovation emphasizes that innovation does not take place in a closed context within the framework of a single organization, but instead often occurs in the interaction between a number of different actors.

- Innovation in the form of system change (Transformative change): a transformative approach to innovation focuses on a more radical change of existing production systems. While innovation systems have primarily been concerned with understanding the systemic nature of innovation, this evolutionary approach has thus added a stronger historical dimension to the systemic: How do innovation systems change over time? The emergence of major societal challenges such as climate crisis, immigration, integration, and economic crisis are examples that require more radical measures and re-configuration of existing produc- tion and innovation systems. Such societal challenges are characterized by being difficult to define, and solutions must often be developed over time and in collaboration between many different actors, and across the public and private sectors.

In this study, it is considered that innovation is built on $\mathrm{R} \& \mathrm{D}$, and both terms play the same role in generating a turnover from product innovations, consequently in creating a new form of value-added; hence, both concepts "R\&D" and "innovation" are interchangeably used.

The problem of the relationship between innovation and economic progress has been in the field of view of researchers for a long time. Schumpeter (1934) was the first one who looked at terms as "innovator", "innovation" from this perspective. It should be mentioned that generations of researchers have demonstrated a wide range of views on this problem: from the mid-50s and until about the mid-80s of the XX century, the concept of exogenous (external) technological progress dominated. This point of view was shared by Tinbergen (1942), Solow (1956), Harrod (1939), etc. Subsequently, this approach was criticized: for example, Nelson and Winter (1984) noted that Solow's theory "does not explain literally productivity growth"; on the other hand, there were those who adhered to Solow's views.

Many studies have shown that scientists nowadays are actively involved in the study of the relationship between the results of innovation policy of the country, innovation activity of the enterprise, and the growth of the national economy.

It should be mentioned that "most research on determining the factors of product innovation, based on the role of $\mathrm{R} \& \mathrm{D}$, use an augmented Cobb-Douglas production function to include R\&D expenditure or an alternative measure of the innovation effort" (Kato, 2012).

For example, Pece et al. (2015) argue that innovation, costs, $\mathrm{R} \& \mathrm{D}$, and investment in technology are the basis for ensuring the competitiveness of the country and sustainable economic growth. Using the example of some countries, namely Hungary, the Czech Republic, and Poland, the dependence 
of long-term economic growth on the innovative potential of the economy was analyzed. As a result, it was argued that economic growth is influenced by factors such as innovation (the number of patents, the level of research and development costs), foreign direct investment, education, and exports. At the same time, Archibugi et al. (2013) claim and prove the absence of a direct relationship between innovation and the economic situation in the country.

Kijek and Matras-Bolibok (2019) consider the interdependence between innovation and such an indicator of the national economy as TFP (total productivity factors). They do emphasize the results of innovative activities of enterprises and consequently on the level of growing economies, that also affected by the territories in which they are located because it is economic growth and geographical agglomeration of economic activity are interdependent processes, which explains why the same. The input data that provide innovative output at different territories have different values. Better results of innovative activity of the enterprises were shown in those regions, in which such activities have already been implemented, and they are associated with the accumulation of knowledge.

The impact on the competitiveness of national economies of innovation potential in EU member counties, such as Austria and Germany, was studied by Lomachynska and Podgorna (2018). GDP and the share of export of goods and services as \% of GDP were used as a dependent variable. Hence, it was revealed that in both countries education and employment policies should be improved and be more oriented towards R\&D development.

Baumann and Kritikos (2016) investigated the link between $\mathrm{R} \& \mathrm{D}$, innovation, and productivity, where the focus was on the input and output in the manufacturing industry.

In addition, there remains a debatable issue about the effectiveness of sources of R\&D funding. For example, Schumpeter (1934) argued that innovations are created by entrepreneurs, but in the later period (1962) concluded about the importance of large enterprises (especially monopolies) for innovative development. Much attention is paid to the impor- tance of the government as a driver of innovation by Mazzucato (2013), and Mazzucato and Perez (2014).

Making an inevitable generalization, it is worth saying that there are two main forms of such support: tax policy and direct government funding. There is no consensus among researchers on this issue, but it is believed that direct financial support from the state is more effective than tax incentives.

Thus, the literature review allows concluding that there is a relationship between the innovative activity of the enterprise and the growth of national economies. At the same time, in different countries, this connection is traced between different indicators that reflect these processes. Nevertheless, there is a lack of investigation of how the R\&D costs contribute to value creation and sustainable transition in the maritime industry. Hence, the current study is relevant.

\section{TREND ANALYSIS OF INNOVATION ACTIVITIES}

According to the European innovation scoreboard (European Commission, 2021), which provides the analysis on innovation performance in EU countries, in 2021 Norway was placed in a group of strong innovators ( $11^{\text {th }}$ position): "Over time, performance relative to the $\mathrm{EU}$ has increased strongly, in particular in 2017 and 2019". It shows that the position has been improved. However, at the same time, Norway is in the lower tier when it comes to intellectual property rights (patents, design, and trademark applications), and sales and export. Both are related to the fact that Norway has a business structure with a lot of activity and value creation in industries that are not characterized by high-tech products. This does not mean that Norway lacks knowledge-intensive industries. Norway is among the countries with a high proportion of export of knowledge-intensive services. What first and foremost draws Norway down in this comparison is the relatively low level of export and innovation in high-tech products.

Hence, it is needed to look at R\&D activities and the maritime industry in particular, which is one 
of the most important export-oriented industries in Norway. It is important to shed the light on the organizational perspective of innovation.

\subsection{An organizational perspective on innovation in the maritime industry}

It should be mentioned that the government has focused on maintaining and strengthening Norwegian marine research. For this reason, in the autumn of 2020, the government issued a report to the Storting (the Norwegian Parliament) on the maritime industry, called "Greener and smarter - tomorrow's maritime industry". In the report, the government writes that it will present a new, updated Maritim21 strategy in 2021. The strategy will provide a comprehensive review of maritime research, development, and innovation, and will also provide a special review of technology and research opportunities related to green shipping and digitization.

The government is committed to increasing the internationalization of Norwegian research, both for strengthening Norwegian competitiveness and for gaining access to a large international knowledge base. In addition, Norway has developed comprehensive public policy instruments for $R \& D$ and business development through the Research Council of Norway, Innovation Norway, SkatteFUNN, and ENOVA (Figure 1):

- Innovation Norway. By financing projects and raising the competence of companies with ambitions for growth and exports, Innovation Norway is helping to create the jobs of the fu-

Source: Author's elaboration.

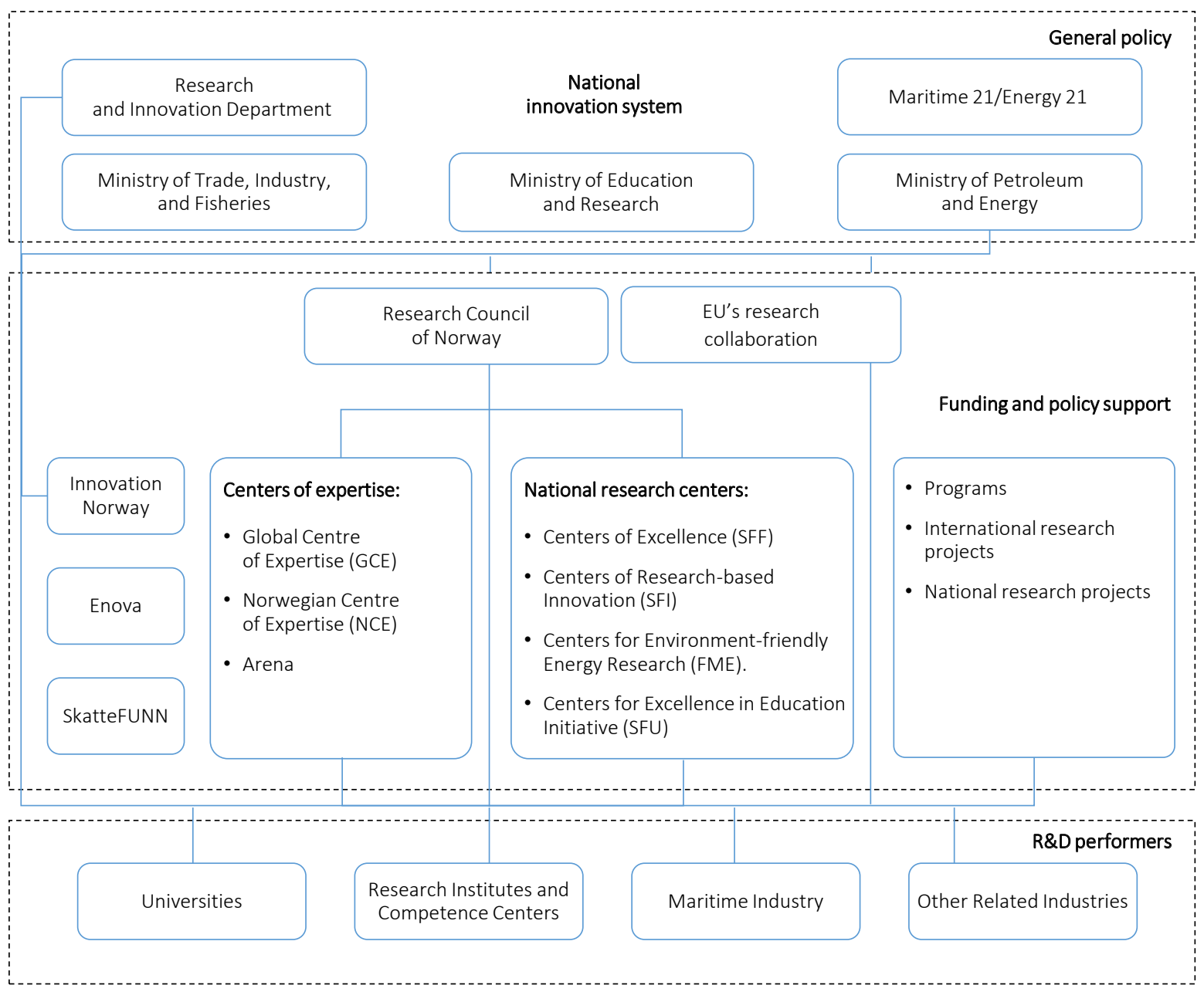

Figure 1. Organizational perspective on innovation in the maritime industry 
ture. It offers services within financing, consulting, expertise, networking, and profiling.

- Enova. Financing of energy- and climate-friendly solutions. Enova contributes to new energy and climate technologies being developed and put into use and can cover part of the additional cost by choosing more energy- and climate-friendly solutions.

- Research Council. Helps companies that carry out innovation projects together with the research community. The funds contribute to companies being able to solve societal challenges, ensure sustainable value creation and economic growth.

- SkatteFUNN. The SkatteFUNN scheme is a tax deduction scheme for business and industry costs for research and development. Through SkatteFUNN, companies can receive project costs as a tax deduction through the tax settlement.

It is believed that the corona crisis stimulates more people to think new, this should also be reflected in the division of those seeking innovation-oriented support since 2020. It is important to examine whether applicants for R\&D and innovation-oriented support during the corona crisis are different from those who usually receive support through business policy instruments (Forskningsrådet, 2020).

Table 1 shows that many applicants are new in 2020 , i.e., $46 \%$ of the applicants who have received a grant so far have not had any innovation-oriented grant in the period 2017-2019.

The largest proportion of new applicants has been observed for Innovation Norway, where almost half of the applicants (49\%) have not received any funding from Innovation Norway, the Research Council, or SkatteFUNN in the previous 3-year period.

Also, according to Figure 1, in Norway, there are several governments supported cluster programs, based on both publicly funded R\&D and the participants' privately funded R\&D: "One of the examples of maritime clusters is the Global Centre of Expertise Blue Maritime Cluster with training activities in Ålesund area, which is funded by private companies, university, and Innovation Norway" (OECD, 2017). The policy aims to promote the construction and operation of greener ships. Therefore, a significant part of the grants from the Research Council of Norway and Innovation Norway goes to various maritime industries. The maritime industries receive a large share of Innovation Norway's total allocations. In the period 2013-2020, the total share was 36\% (NOK 22.3 billion) of the total (NOK 61.4 billion). This is based on a total of 7,436 commitments to customer projects within these maritime industries.

In addition, Norway participates fully in the EU's research collaboration Horizon Europe, where there are several blue initiatives in the period 2021-2027. The government is working on facilitating the EU's blue programs so that they respond to key knowledge needs for Norwegian maritime industries. The institutions' research vessels, research stations, and laboratories form a significant part of state-owned marine research infrastructure.

\subsection{R\&D expenditure in Norway and other Scandinavian countries}

A total of about NOK 70 billion was spent on research and development work (R\&D) in Norway in 2017. In current prices, R\&D efforts increased

Table 1. Number of applicants with funding in 2020 by instrument actor

Source: Statistics Norway (2021), Innovation Norway (2020), the Research Council of Norway (2019).

\begin{tabular}{|c|c|c|c|c|}
\hline Instrument actor & $\begin{array}{c}\text { Applicants with a grant in } \\
2017-2019\end{array}$ & New applicants & Total & $\begin{array}{c}\text { Share of new } \\
\text { applicants }\end{array}$ \\
\hline Innovation Norway & 1,468 & 1,435 & 2,903 & $49 \%$ \\
\hline Research Council & 317 & 62 & 379 & $16 \%$ \\
\hline SkatteFUNN & 845 & 393 & 1,238 & $32 \%$ \\
\hline Total & 2,009 & 1,713 & 3,722 & $46 \%$ \\
\hline
\end{tabular}

Note: based on completed applications as of September 21, 2020 (as of October 12 for SkatteFUNN applications). 
Table 2. R\&D expenditure by performing sector and a total number of R\&D man-years in 2015,2016 , and 2017, mill. kroner and percentage change (current prices)

\begin{tabular}{|c|c|c|c|c|}
\hline Sector & 2015 & 2016 & 2017 & Change 2016-2017 \\
\hline Business sector (BERD) & 27,783 & 29,489 & 32,573 & $10 \%$ \\
\hline Higher education sector (HERD) & 18,709 & 20,636 & 23,240 & $13 \%$ \\
\hline Government sector (GOVERD) & 13,718 & 13,220 & 13,900 & $5 \%$ \\
\hline
\end{tabular}

NOTE: *Business enterprise expenditure on R\&D (BERD) represents the component of gross domestic expenditure on R\&D (GERD) incurred by units belonging to the Business enterprise sector; HERD - incurred by units belonging to the Higher education sector; GOVERD - the component of GERD incurred by units belonging to the Government (public) sector (OECD, 2015). Private Non-Profit (PNP) sector is insignificant in Norway and is therefore included in the Government sector of the OECD statistics (Kaloudis \& Rørstad, 2006).

significantly, by more than NOK 6 billion or $10 \%$ from 2016. The number of R\&D man-years in 2017 increased by just over 3,000 from the previous year, to 47,000 . The share of R\&D expenditure in GDP is estimated at $2.1 \%$. Staff growth explains a large part of the increase in R\&D expenditure. In 2017, a total of almost 47,000 R\&D man-years were carried out.

According to Table 2, it is clear that the business community is responsible for the largest R\&D effort: the sector spent NOK 32.6 billion on R\&D in 2017 , which was $47 \%$ of total R\&D expenditure. This was followed by the higher education sector with NOK 23.2 billion, and the public sector with almost NOK 14 billion. Almost 70 billion expenditures on R\&D are estimated at $2.11 \%$ of Norway's gross domestic product (GDP), up from $2.03 \%$ in 2016.

Compared with 2016, the percentage growth was the greatest in the higher education sector. The business community increased its R\&D efforts by more than NOK 3 billion from 2016 (by 10\%). The weakest growth is observed in the public sector, where $\mathrm{R} \& \mathrm{D}$ expenditure increased by $5 \%$ or about NOK 700 million from 2016.

If compare with other countries, total investment in R\&D in Norway is more than $2 \%$ of GDP in 2018, and this result is still below the OECD average (Figure 2).

Until 2017, Norway experienced stronger R\&D growth than most other comparable countries, primarily due to an increase in Norwegian R\&D grants. Overall, this indicates that Norway's growth in R\&D spending as a share of GDP is stabilizing now.

\section{3. $R \& D$ expenditure in the maritime industry}

Results from Figure 3 show that the share of Norwegian R\&D expenditures in the building

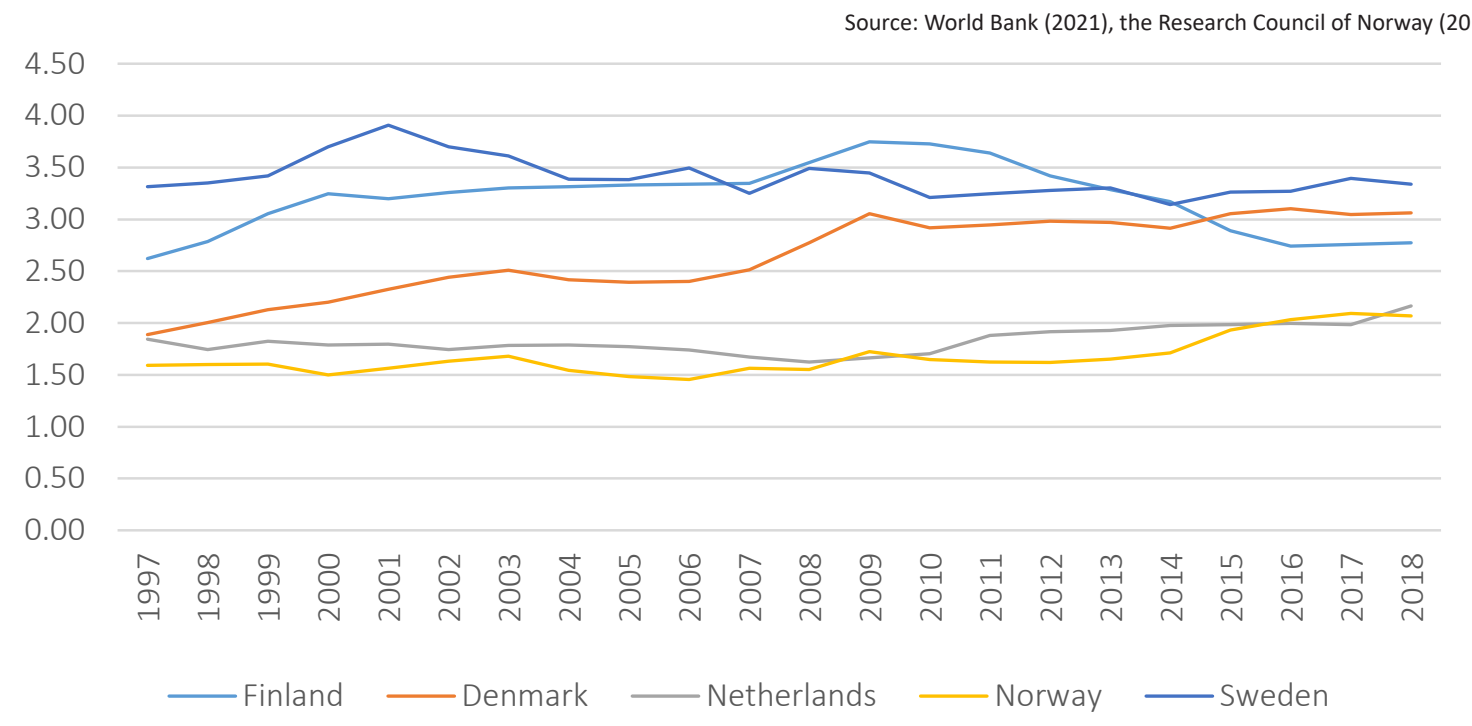

Figure 2. GERD as a share of GDP for selected countries, 1997-2018 
2.5

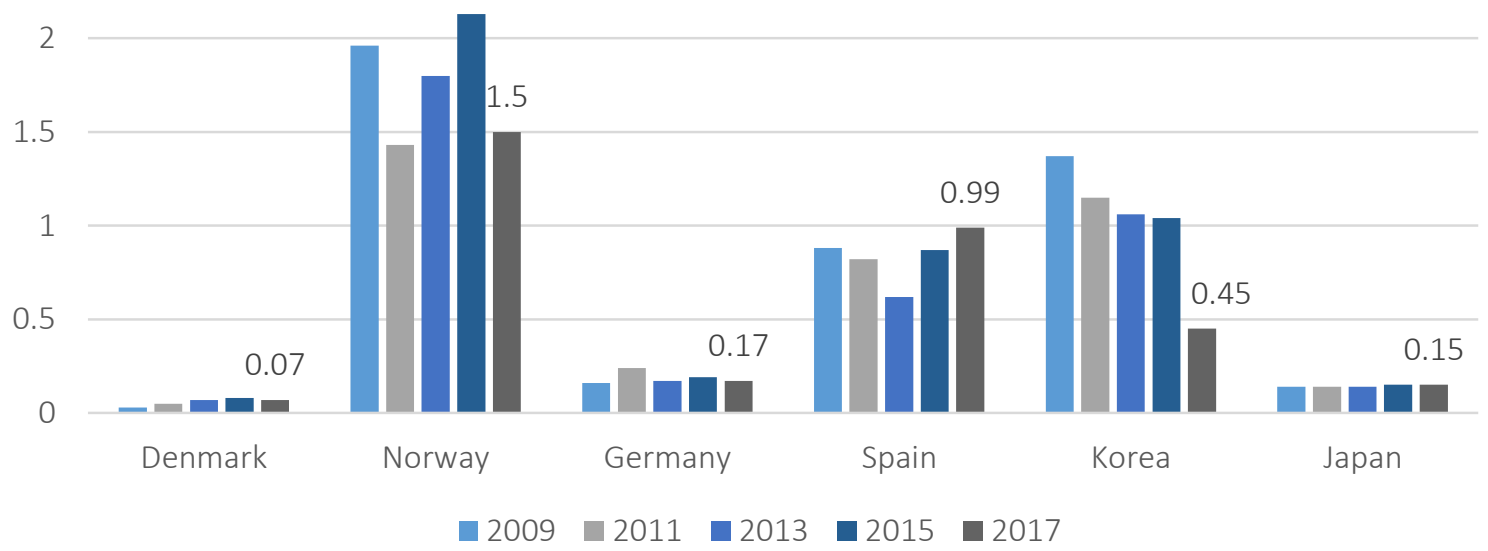

Figure 3. R\&D expenditure in the building of ships as a share of total BERD, 2009-2017

of ships to total R\&D expenditures are even better rather than in those shipbuilding countries: according to Statista (2021), the biggest shipbuilding nations in 2019 were China, South Korea, and Japan, thus it was decided to add to analysis above-mentioned Asian countries.

According to OECD statistics, it was discovered that the situation in Norway is better if comparing figures that apply to the development and construction of ships. In 2017, the share of R\&D expenditure in shipbuilding in total BERD was $1.5 \%$, while in Korea the result was $0.45 \%$ (Figure 3).
Figure 4 clearly presents that Norway has the lowest level of BERD as a proportion of GERD, at the same time BERD in shipbuilding is scored as the highest. In the middle of the matrix, one can see Korea and Spain while such countries as Germany and Japan with high-level general business expenditure on R\&D and with a low level of business R\&D expenditures in shipbuilding are in the left upper section. In addition, Denmark is placed in the left bottom section that characterized this country as a country with a low score of both parameters.

Moreover, a high proportion of BERD in those shipbuilding nations is funded by the govern-

Source: OECD (2021).

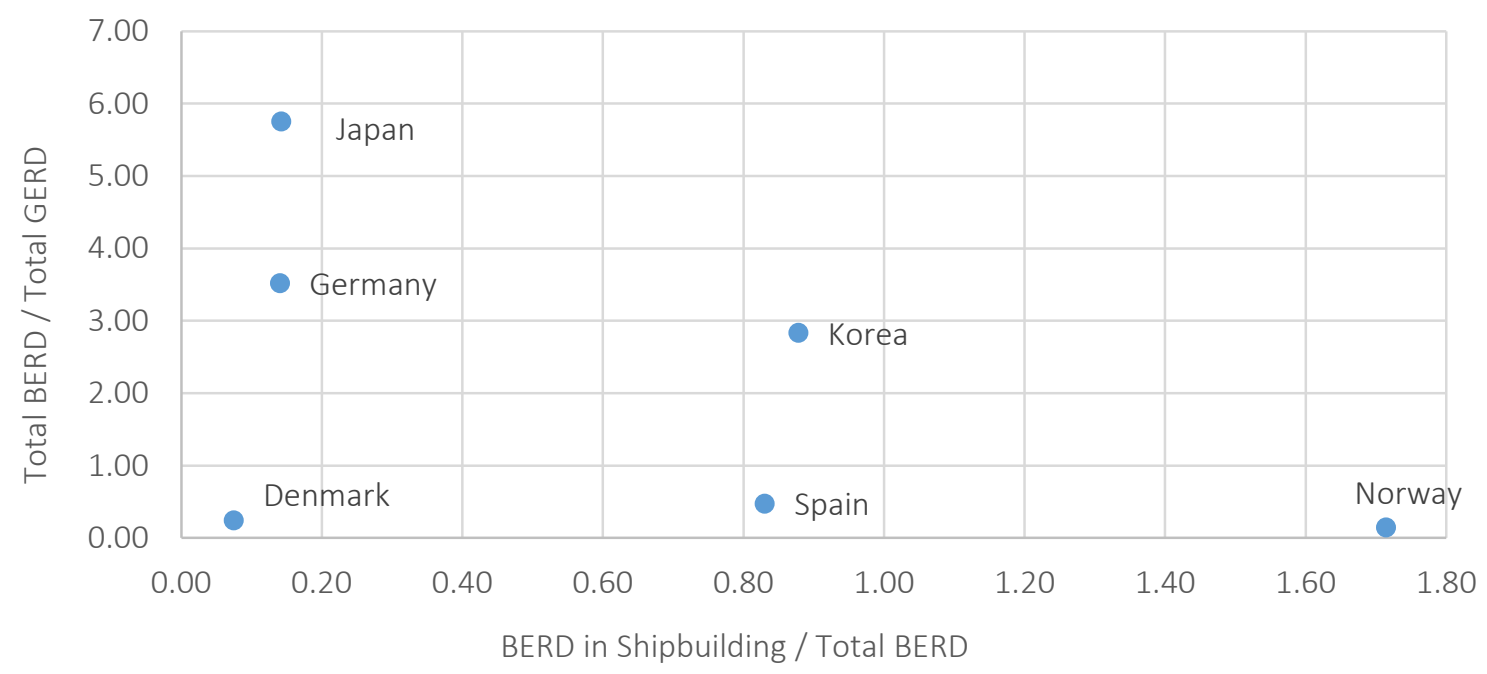

Figure 4. Relation between BERD as a proportion of GERD and BERD in Shipbuilding industry as a proportion of total BERD 


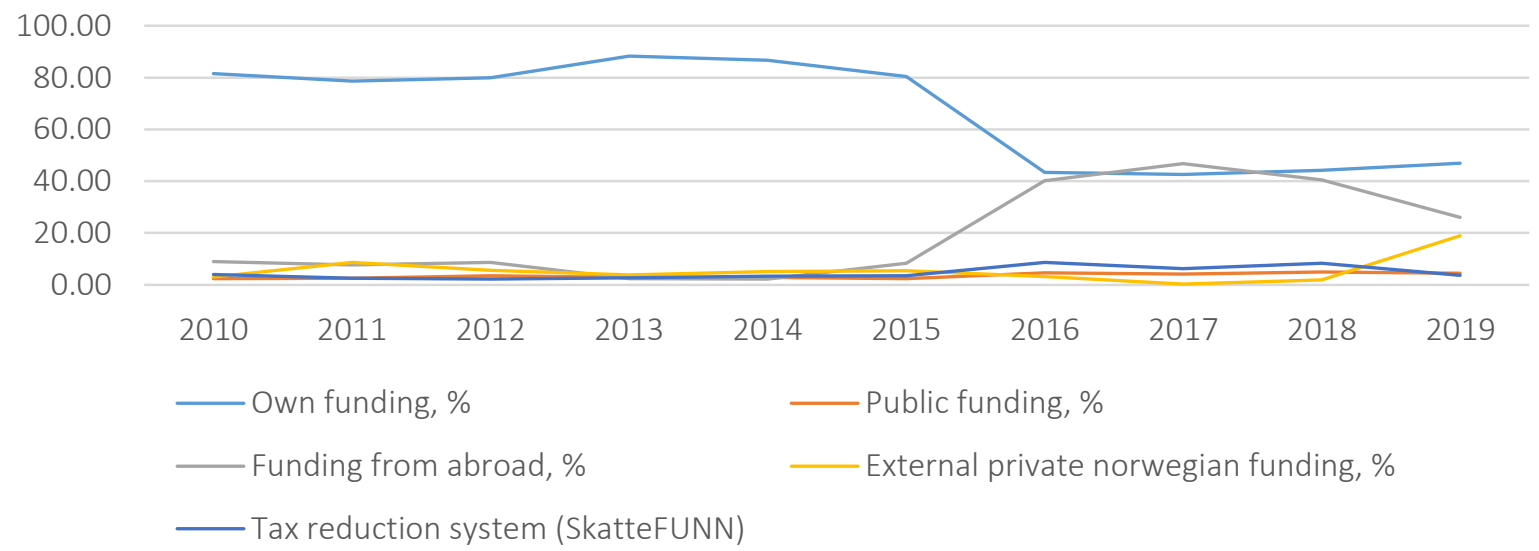

Figure 5. Funding of BERD in Building of ships and boats, $\%$ of total funding

ment. For example, Spain supports the shipbuilding industry through both total R\&D support schemes and export financing (Haugland et al., 2021). In Germany, the government supports maritime R\&D activities in the shipbuilding and marine supply industry with different programs, such as "Shipping and Marine technology for the $21^{\text {st }}$ Century" that aims to help German firms to maintain their competitiveness in the global market and develop new technologies (OECD, 2016).

When it comes to Norway, the statistic is quite different. According to Figure 5, the BERD in the shipbuilding industry until 2015 (80\% of total amount) was mostly funded by business, but the situation changed significantly in 2016, where funding from abroad contributed to a large extend in funding of $\mathrm{R} \& \mathrm{D}$ activities in the industry. Concerning public support, it remains humble (2-4\%).

It should be noted, the maritime sector, in general, has a higher return on capital than other major Norwegian industries such as the technology industry, the consumer goods industry, the process industry, and seafood (Jakobsen et al., 2014). Considering that the Norwegian wage level is significantly higher than neighbor trading partners, the importance of knowledge and competence in international competition is significant. If the maritime industry and the offshore supplier industry are to maintain or strengthen their international competitive position, they must find solutions that compensate for the high wage level, which in practice means innovation.
Thus, the following analysis shows that there is a need for an in-depth study of how such policy instruments as R\&D in the maritime industry can contribute to value creation in the maritime industry and it is vitally important. This enables the early identification of problems so that solutions can be proposed.

\section{DATA AND METHODOLOGY}

The OECD (2021) and Statistics Norway (2021a, 2021b) databases were utilized in this study. Among the most relevant quarterly data for estimation of innovation activity for 10 years period (2010-2019), there are value added, trade indicator, wages and salaries of persons involved in R\&D activities, innovation turnover, and BERD in the industry of building of ships and boats.

In addition, it was decided to carry out structural and dynamic analysis for investigation of R\&D expenditures within three main sectors of the economy: primary, secondary, and services. Dynamic analysis provides information about the historical development of an indicator, but more benefits can be gained by performing dynamic comparison analysis. For this reason, it was decided to conduct a comparative analysis of the growth rates of $\mathrm{R} \& \mathrm{D}$ expenditures by industry using Relative Performance Ratio $(R P R)$ :

$R P R=\frac{\text { Growth rate of } R \& D \text { in industry } i}{\text { Growth rate of } R \& D \text { in industry } j}$

The goal of this paper was to study the relation of R\&D investment and how it contributes to the in- 
crease in value creation in the maritime industry. Thus, the above-mentioned parameters were selected as dependent variables for correlation and linear regression analysis (all variables are taken for ships, boats, and the oil platforms industry). As independent variables, the following indicators were chosen: trade indicator $\left(X_{1}\right)$, the total $\mathrm{R} \& \mathrm{D}$ in the business enterprise sector $\left(X_{2}\right)$, the costs for hired personnel $\left(X_{3}\right)$; volume of sold innovative products $\left(X_{4}\right)$.

It should be mentioned that in this study it was decided to use Hodrick-Prescott filter to remove the cyclical component of a time series from raw data.

The analysis was performed by using natural log values:

$$
\begin{aligned}
& \ln V A_{t}=\alpha+\beta_{1} \ln T R I_{t}+\beta_{2} \ln B E R D_{t}+ \\
& +\beta_{3} \ln S A L_{t}+\beta_{4} \ln T / O_{t}+\varepsilon_{t},
\end{aligned}
$$

where $\ln V A_{t}$ is the logarithm of value-added, $\alpha$ is intercept, $\beta_{j}$ are unknown parameters; trade indicator $\ln T R I_{t}$, the volume of $\mathrm{R} \& \mathrm{D}$ expenditures in the Business Enterprise sector $\ln B E R D_{t}$, costs for hired personnel, involved in R\&D activities $\ln S A L_{t}$, turnover from product innovations $\ln T / O_{t}$.

\section{RESULTS}

Before conducting the analysis, it is important to see how the R\&D costs contribute to a sustainable transition in the maritime industry in general. Sustainability is made up of three pillars: the economy, society, and the environment. The further study will be focused on economic parameters, but it was decided to find out how the invested costs correlate with a sustainable transition of the industry. According to the achieved results, $\mathrm{R} \& \mathrm{D}$ expenditures in the Business Enterprise sector $\left(\ln B E R D_{t}\right)$ and costs for hired personnel, involved in R\&D activities $\left(\ln S A L_{t}\right)$ have negative correlation with $\mathrm{CO} 2$ emission indicator $-(-0,83)$ and $(-0,51)$ respectively (Table 3$)$.

Table 3. Correlation between $\mathrm{CO} 2$ emissions and investigated parameters of the model, 2010-2019

\begin{tabular}{c|c|c|c|c|c}
\hline \multirow{2}{*}{ CO2 } & $\mathbf{V A}_{\mathbf{t}}$ & $\mathbf{T R I}_{\mathbf{t}}$ & BERD $_{\mathbf{t}}$ & $\mathbf{S A L}_{\mathbf{t}}$ & $\mathbf{T}_{\mathbf{t}}$ \\
\cline { 2 - 6 } & 0.7545 & 0.7446 & -0.8258 & -0.5125 & 0.3760 \\
\hline
\end{tabular}

Hence, the results prove that $R \& D$ activities in the industry are helping to save the environment and to solve some of the biggest pollution concerns. Hence, the next step is to investigate how innovative activities contribute to value creation.

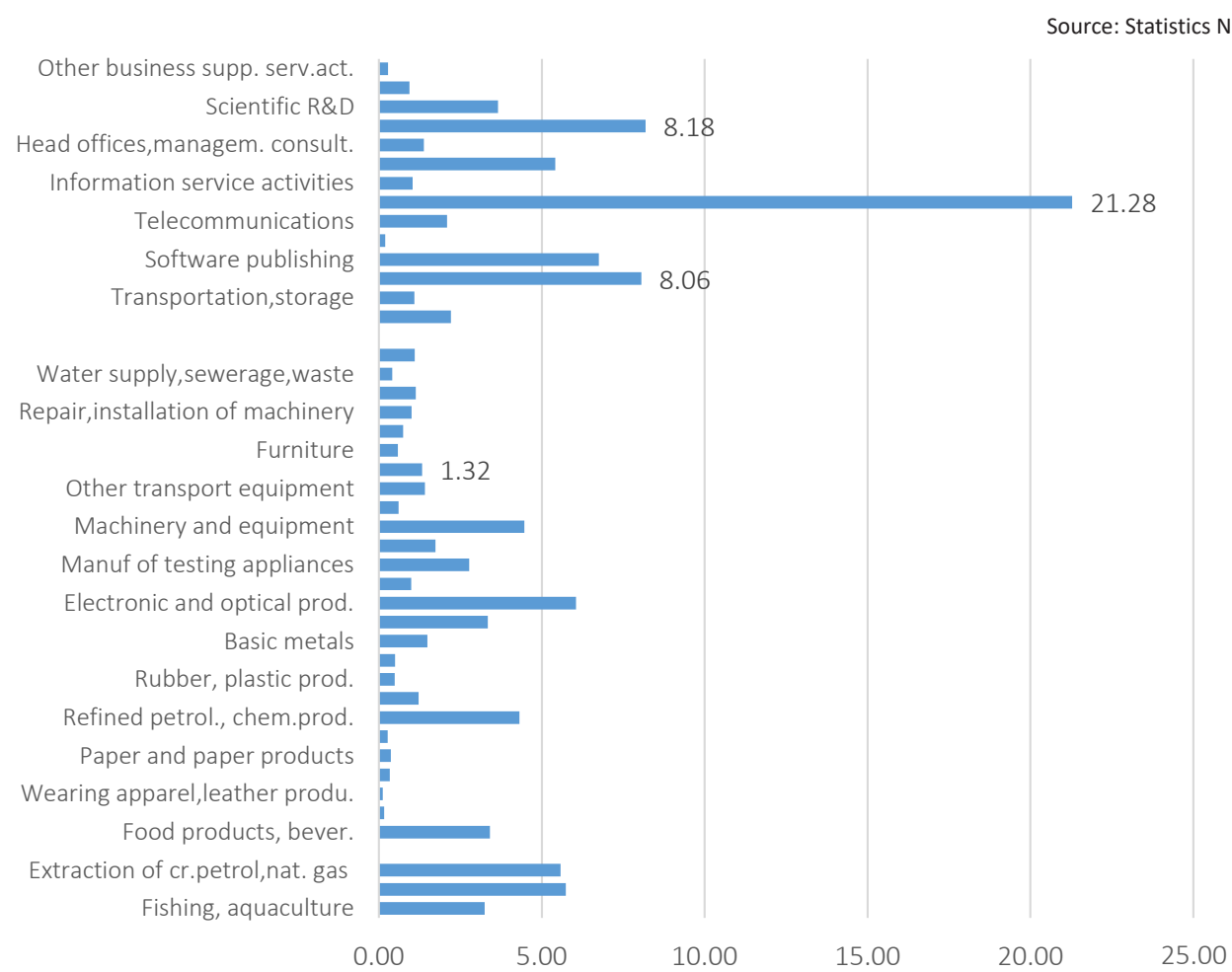

Figure 6. Structure of business enterprise R\&D expenditure by industry, 2019 


\subsection{Structural analysis}

The R\&D expenditures structure broken down by industries is given in Figure 6.

Structural analysis of R\&D expenditures within the industries shows that the greatest concentration of the funds invested in R\&D occurs in the key application service industry for the $21^{\text {st }}$ century such as computer programming, consultancy, where the share of BRED was $21.28 \%$; on the second and the third places - publishing activities and architecture, engineering activities with the share of $8.06 \%$ and $8.18 \%$ respectively. When it comes to the shipbuilding industry the share of $\mathrm{R} \& \mathrm{D}$ expenditures was quite low $-1.32 \%$.

\subsection{Dynamic analysis}

The information in Table 4 reveals that the strongest growth rate of $\mathrm{R} \& \mathrm{D}$ expenditure during the last years can be seen among the companies in the secondary industry, especially in the motion picture, video and TV production, sound recording, and music industry (35: horizontal line), as it has a leading position among all industries.

In addition, this industry showed a stronger growth rate of $R \& D$ expenditures, compare to general $\mathrm{R} \& \mathrm{D}$ expenditures growth (diagonal line) during the analyzed period of 2007-2019.
If to talk about the industry of building ships and boats (23: horizontal line), here a low level of RPR is observed. That means the growth rate of $R \& D$ expenditure during the analyzed period (20072019) had a lower level comparing to the growth rate in other industries.

\subsection{Correlation analysis}

In addition, it was interesting to investigate the correlation between product innovators' turnover and R\&D expenditures within all industries to find out the link between innovation activity and productivity (input and output).

Calculations showed a positive correlation between the scale of funding for innovation activity and the turnover for companies in the primary industry (Figure 7).

Nevertheless, the correlation analysis presented in Figure 7 reveals that there was a negative relation between turnover and R\&D expenditures mostly in half segments of secondary industry. The same applies to the industry - building of ships and boats.

\subsection{Regression analysis}

In the proposed regression analysis, the $p$-values of dependent variables were calculated to compare with the level of significance. The results of the regression analysis are depicted in Table 5 .

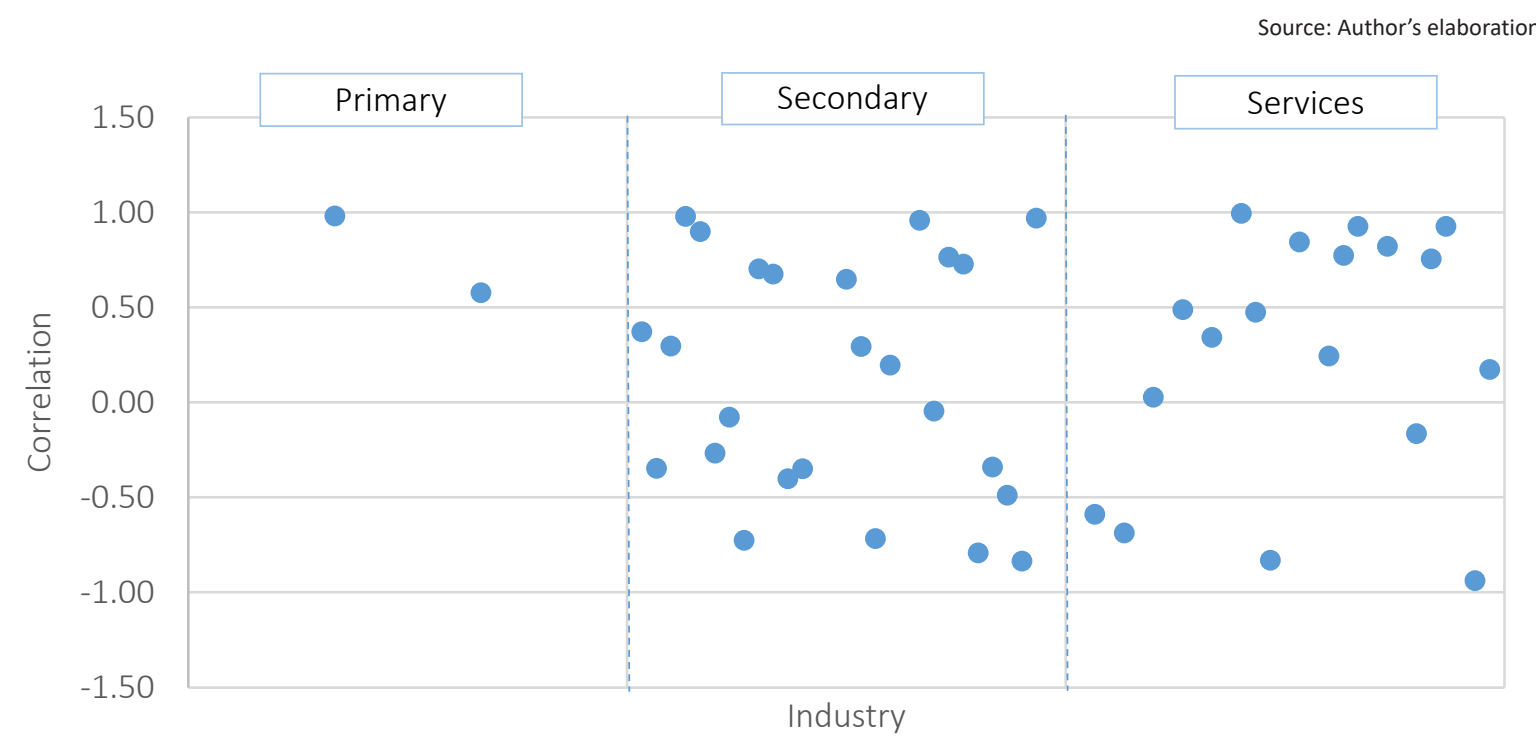

Figure 7. Correlation between product innovators' turnover and R\&D expenditures by industry, 2013-2018 
Table 4. Comparison growth-rate analysis of R\&D expenditure by performing industry, percentage change (compare to other industries)

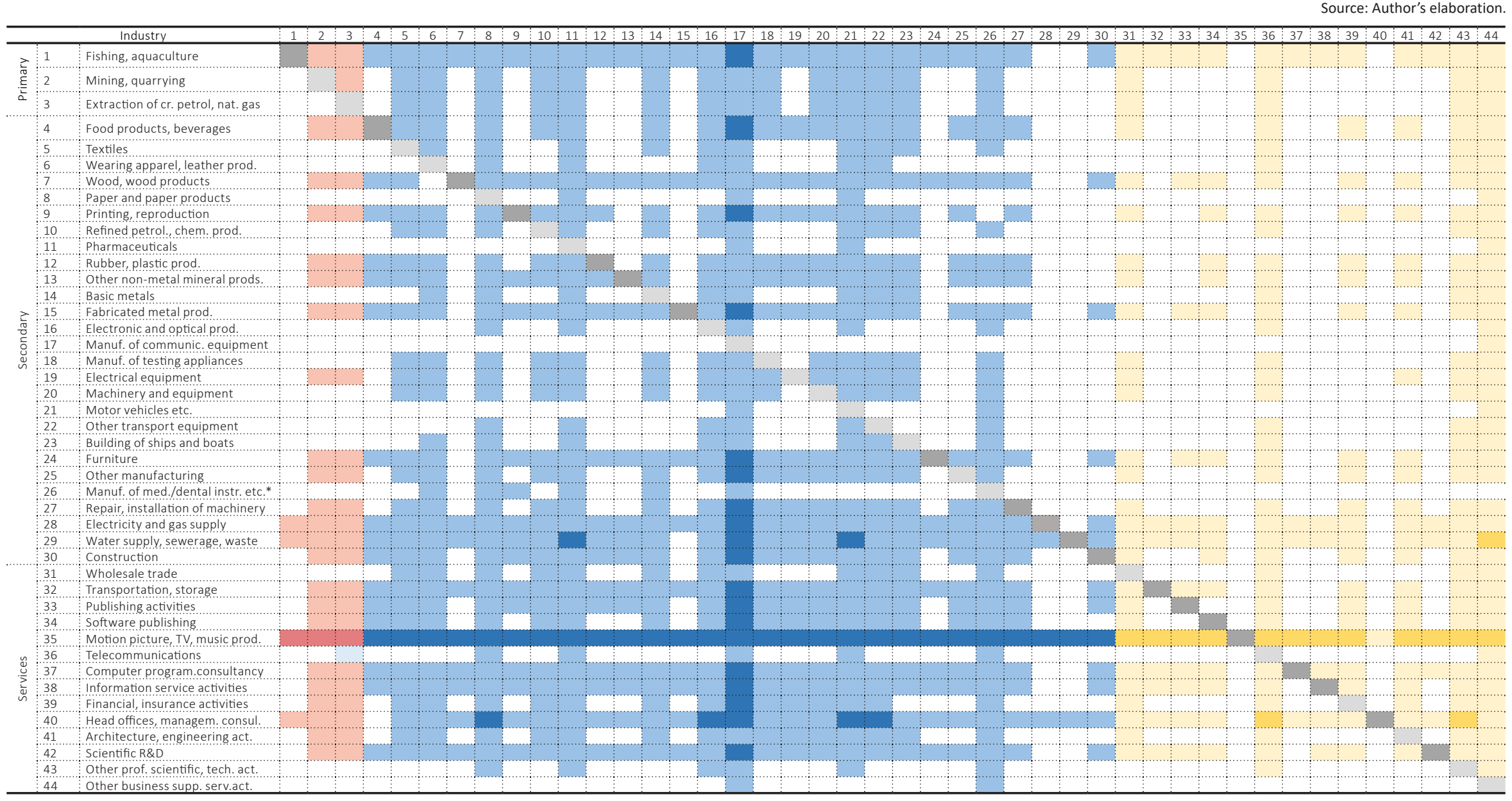

Note: * - this statistic presents the data for all industries for the period 2007-2019, except the manufacture of medical and dental instruments and supplies, where data is available for the period 2007-2013. Diagonal line: dark grey color indicates the stronger growth rate of R\&D expenditures in industry $i$, compare to R\&D expenditures in all industries $\Sigma j$; light grey color lower growth rate. Horizontal line: dark color indicates the stronger growth rate of R\&D expenditures in industry $i$, compare to industry $j$. For example: 
Table 5. Regression analysis results for $\operatorname{lnV} A_{t}$

Source: Author's elaboration.

\begin{tabular}{|c|c|c|c|c|}
\hline Parameter & Coefficients & Standard Error & $t$ Stat & $P$-value \\
\hline Intercept & 1.18 & 0.94 & 1.26 & 0.22 \\
\hline InTRI & -0.35 & 0.03 & -10.60 & 0.00 \\
\hline $\ln B E R D_{t}$ & 0.50 & 0.09 & 5.48 & 0.00 \\
\hline InSAL & 0.06 & 0.02 & 3.87 & 0.00 \\
\hline $\ln T / O_{t}$ & 0.81 & 0.06 & 13.23 & 0.00 \\
\hline Prob $>F$ & 0.00 & & & \\
\hline$R^{2}$ & 0.99 & $\operatorname{Adj} . R^{2}$ & 0.97 & \\
\hline
\end{tabular}

According to Table 5, the following regression was obtained:

$$
\begin{aligned}
& Y=1.18-0.35 X_{1}+0.50 X_{2}+ \\
& +0.06 X_{3}+0.81 X_{4} .
\end{aligned}
$$

The value of the coefficient of determination for the period under analysis is equal to 0.99 , which tells about the good ability of the model to explain and predicts future outcomes. The statistical significance of the obtained results was checked by F-statistics: the obtained value is greater than F-tables, hence, the null hypothesis is rejected. The verification of indicators in the regression model is checked using Student's t-test with a 95\% confidence level. Thus, the indicators that have the greatest positive impact on value-added are $\mathrm{R} \& \mathrm{D}$ expenditures in the business enterprise sector (ln$B E R D$ ) and turnover from product innovations $\left(\ln T / O_{t}\right)$. Also, it was revealed that there is a negative impact of trade indicator on value creation, where $\beta$ parameter is $(-0.35)$.

Hence, the results of the analysis show the significance of innovations and their role in value creation. Nevertheless, the model also highlights the problems in the maritime industry when it comes to the trade balance. For the Norwegian maritime industry, the export markets are more important than the domestic markets. However, most of the vessels are built for domestic purposes. Moreover, the Norwegian industry outsources most of the ship's parts, while the final ship construction is done in Norway. Obviously, the upcoming challenge for the shipbuilding industry is the loss of competence, when in-house production is critical for survival: production provides the greatest access to issues and thereby opportunities for innovation.

Behind Norwegian shipyards' reduced market shares in the construction of vessels since the be- ginning of the 2000s is probably twofold. First, competition has intensified from countries with lower wage levels, especially China, but also other Asian and European shipyards. Fast delivery is especially important in a good market, and many shipping companies may therefore have chosen competing shipyards in other countries due to shorter delivery times. Secondly, the shortcomings of the formation and implementation of innovation policy of the country. The last factor can be crucial, not least how protectionism affects the maritime industry. A study from the International Chamber of Shipping, which was published in February 2021, shows that Norway also ends up in $15^{\text {th }}$ place here, among 46 maritime nations (International Chamber of Shipping, 2021). It may indicate that the Norwegian authorities are not doing enough to protect one of the most important export-oriented industries in Norway.

\section{DISCUSSION}

Shipbuilding is a complicated industry: the yard must bear most of the risk, and from an investor's point of view, this is not a particularly attractive industry, as one rarely is paid for this risk. Menon Economics and BCG prepared a comprehensive and well-descriptive report (Haugland et al., 2021) on the state of the Norwegian shipbuilding industry. Several factors pointed out are that over time have weakened the competitiveness of Norwegian shipyards - the Generalization Act gives disadvantages regarding personnel costs, a high degree of outsourcing has weakened internal competence, competence gaps in project management, and drop-outs of important markets have resulted in large restructuring costs. If Norwegian shipbuilding is willing to have a future in the long run, the Norwegian cluster must become world champions 
in handling variability and complexity. One of the proposals in the report is to increase the use of digital tools, automation, and robotics.

One can talk about digital twins and virtual prototyping, but these are technologies that have emerged because of good industrial craftsmanship and collaboration of the partners. This craft requires experience and appropriate industrial strategy, that should be created and applied to shipyards to transform them into "smart shipyards" "Shipyard 4.0" (Haugland et al., 2021).

Another point is that a new era of digital transitions is creating new organizational models, affect the relationships between the actors, in other words - new relationships require new business models (Koilo, 2021). Presently, several programs in Norway aim to help the industry with the development and application of digital transformation technology. One of them is SFI MOVE at NTNU in Ålesund. The goal of the project is to establish a world-leading research and innovation center for demanding marine operations. It is believed that the digital transformation of the maritime industry will allow improving the cost-efficiency of marine operations through reduction of total field operational costs and safer operations in the future. Therefore, within the scope of the project, SFI MOVE aims to investigate, how new innovative solutions can help the industry to create, deliver, and capture value, i.e., create a new business model.

\section{CONCLUSION}

According to the European innovation scoreboard, Norway's position has been improved significantly: in previous editions, Norway has placed itself around 16-17, it has been described as a"moderate innovator". In 2021, it is ranked number 11 and placed among the foremost in the group of a «strong innovator». The main explanation for Norway's progress is in 1) employment impacts, 2) linkages, and 3) attractive research systems. At the same time, Norway is in the lower tier when it comes to intellectual property rights, sales, and export. The last one is quite a crucial factor. The numbers speak for themselves. Norwegian foreign trade for 2020 shows a decline in merchandise exports, and the export value has fallen by $15.5 \%$ since 2019 . One can blame the pandemic and oil and gas crisis for these consequences, nevertheless, other Scandinavian countries show better performance in the export revenue.

Therefore, all the above-mentioned highlights that there are problems, and investigation is needed. It was revealed that the impact of R\&D investment on the economic growth of the country, companies' performance has been widely discussed in both academia and the business arena. However, in existed economic literature there is a lack of study, how such public policy instruments as R\&D in the maritime industry can contribute to value creation, and does innovation technology expenditures stand for sustainable transition?

To identify and study these relationships in the maritime industry, correlation and linear regression analyses were used for the period 2010-2019. The OECD and Statistics Norway databases were utilized, which makes it possible to develop an economic-mathematical model of the impact of innovation on value creation in the maritime industry in Norway.

The regression analysis showed that the impact of turnover and $R \& D$ costs on value creation in the industry of building ships and boats has a positive direction; nevertheless, the negative impact of the trade indicator on value-added underlines the existing problems and difficulties in increasing exports. Overall, the results point to a positive impact of $R \& D$ spending, and at the same time, the new technologies still do not strengthen the industry on the global market.

Hence, it does not mean that Norway lacks innovation activities or advanced technology. Nevertheless, several reasons draw down the efficiency of R\&D utilization in export-oriented industries. 
The first one: the international market requires that industry must be adaptable, and thus more public incentives are needed to promote exports from Norway. Here among those measures can be: 1) new long-term industrial strategy, 2) support schemes (industry should have a better degree of financing and higher guarantee), and 3) educational offerings (a modern and future-oriented production company will need candidates with expertise, preferably in all areas).

The second one: green and digital transition in the maritime industry together with public support and such policy instrument as $\mathrm{R} \& \mathrm{D}$ can contribute to creating new products; also it can strengthen an existing product or service with additional features. Another aspect is that new things affect the relationships between the actors, thus new relationships require new business models.

Thus, the export industry must constantly look for new opportunities, be updated to international market requirements, and new business models are required. Hence, both the cluster and the government must focus on this issue.

\section{AUTHOR CONTRIBUTIONS}

Conceptualization: Viktoriia Koilo.

Data curation: Viktoriia Koilo.

Formal analysis: Viktoriia Koilo.

Funding acquisition: Viktoriia Koilo.

Investigation: Viktoriia Koilo.

Methodology: Viktoriia Koilo.

Project administration: Viktoriia Koilo.

Resources: Viktoriia Koilo.

Software: Viktoriia Koilo.

Supervision: Viktoriia Koilo.

Validation: Viktoriia Koilo.

Visualization: Viktoriia Koilo.

Writing - original draft: Viktoriia Koilo.

Writing - review \& editing: Viktoriia Koilo.

\section{ACKNOWLEDGMENT}

The study is supported by a grant from the Research Based Innovation "SFI Marine Operation in Virtual Environment (SFI-MOVE)" (Project no: 237929) in Norway.

\section{REFERENCES}

1. Archibugi, D., Filippetti, A., \& Frenz, M. (2013). The impact of the economic crisis on innovation: Evidence from Europe. Technological Forecasting \& Social Change, 80(7), 1247-1260. https://doi. org/10.1016/j.techfore.2013.05.005

2. Basso, M. N., Hernes, S., Albertsen, M., Erraia, J., Fjose, S., \& Jakobsen, E. (2021). Et årlig dypdykk i Norges eksport (Report). Menon Economics. (In Norwegian). Retrieved from https:// www.menon.no/wp-content/ uploads/2021-58-Eksportmeldingen-2021.pdf

3. Baumann, J., \& Kritikos, A. (2016). The Link Between R\&D, Innovation And Productivity: Are Micro Firms Different? Research Policy, 45(6), 1263-1274. https://doi. org/10.1016/j.respol.2016.03.008

4. Brussels. (2021). Nine types of innovation entrepreneurs should know about. Retrieved from https://1819.brussels/en/infor- mation-library/rd-innovationpartnerships/9-types-innovationfor-companies

5. ECORYS. (2014). Study on Deepening Understanding of Potential Blue Growth in the EU Member States on Europe's Atlantic Arc (Final Report FWC MARE/2012/06SC C1/2013/02). DG Maritime Affairs and Fisheries.

6. Energi Klima. (2021). Det grønne skiftet: Hvordan finansiere den 
store oppskaleringen? (In Norwegian).

7. European Commission. (2021). European innovation scoreboard 2021. Retrieved from https:// ec.europa.eu/growth/industry/ policy/innovation/scoreboards_en

8. Forskningsrådet. (2020). Bidrar virkemiddelapparatet til nytenking under krise? (In Norwegian). Retrieved from https://www. forskningsradet.no/indikatorrapporten/les-mer/bidrar-virkemiddelapparatet-til-nytenking-underkrise/

9. FS UNEP Centre. (2020). Global Trends in Renewable Energy Investment 2020. Retrieved from https:// www.fs-unep-centre.org/globaltrends-in-renewable-energyinvestment-2020/

10. Gilje, K. H., Skogli, E., Baustad, H., \& Seeberg, A. S. (2018). Nåtidsanalyse av innovasjonsaktivitet $i$ kommunesektoren (Report). Menon Economics. (In Norwegian). Retrieved from https://www.forskningsradet.no/contentassets/2fd 460a1f6e044999f36b327950e4463/ natidsanalyse-av-innovasjonsaktivitet-i-kommunesektoren.pdf/

11. Grytten, O. H., Lindmark, M., \& Minde, K. B. (2020). The wealth of nations and sustainable development: energy intensity and the environmental Kuznets curve. Environmental Economics, 11(1), 110-123. http://doi.org/10.21511/ ee.11(1).2020.10

12. Harrod, R. F. (1939). An essay in dynamic theory. The Economic Journal, 49(193), 14-33. https:// doi.org/10.2307/2225181

13. Haugland, M., Abrahamoglu, S., Berle, Ø., Helseth, A., Jakobsen, E., \& Nyheim, E. (2021). Norske skipsverft - aktivitet, konkurransesituasjon og rammebetingelser (Report). Menon Economics. (In Norwegian). Retrieved from https://www. regjeringen.no/contentassets/38a 7dfcd72fe40ab8cf7b4d0ea5b495f/ menon-economics_bcg_norskeskipsverft-aktivitet-konkurransesituasjon-og-rammebetingelser. pdf
14. Innovation Norway. (2021). Some main results from Annual Report 2020. Retrieved from https:// www.innovasjonnorge.no/en/ start-page/about/facts-andnumbers/\#: :text=Record\%20 year $\% 20$ in $\% 20$ number $\% 20$ of, $75 \% 20$ per $\% 20$ cent $\% 20$ from $\% 20$ 2019

15. International Chamber of Shipping. (2021). Protectionism in Maritime Economies Study: Summary Report. Retrieved from https://www.ics-shipping.org/ publication/protectionism-inmaritime-economies-study-summary-report/

16. Jakobsen, E. J., Fjose, S., Mellbye, C., Wifstad, K., \& Guldbrandsen, M. U. (2014). Evaluering av Innovasjon Norges støtte til maritim næring (Report). Menon. (In Norwegian). Retrieved from https://www.menon.no/wp-content/uploads/13menon-rapport3-2014-evaluering-av-in-stotte-tilmaritim-naring.pdf

17. Kaloudis, A., \& Rørstad, K. (2006). Analysis of public ReD funding in Norway: ERAWATCH ReD Specialisation (NIFU working report 2006:51). Retrieved from https://www.nifu.no/publications/1031019/

18. Kato, T. (2012). Advances in the Economic Analysis of Participatory and Labor-Managed Firms. 凶Emerald Publishing Limited. Retrieved from https://www. emeraldgrouppublishing.com/ archived/products/books/series. htm\%3Fid\%3D0885-3339

19. Kijek, T., \& Matras-Bolibok, A. (2019). The relationship between TFP and innovation performance: evidence from EU regions. Equilibrium: Quarterly Journal of Economics and Economic Policy, 14(4), 695-709. http://doi.org/10.24136/ eq.2019.032

20. Koilo, V. (2021). Developing new business models: Logic of network value or cross-industry approach. Problems and Perspectives in Management, 19(2), 291-307. https://doi.org/10.21511/ ppm.19(2).2021.24

21. Leonard-Barton, D., \& Kraus, W. A. (1985). Implementing New
Technology. Harvard Business Review. Retrieved from https://hbr. org/1985/11/implementing-newtechnology

22. Lomachynska, I., \& Podgorna, I. (2018). Innovation potential: impact on the national economy's competitiveness of the EU developed countries. Baltic Journal of Economic Studies, 4(1), 262-270. https://doi.org/10.30525/22560742/2018-4-1-262-270

23. Mazzucato, M. (2013). The Entrepreneurial State: Debunking Public vs. Private Myths in Risk and Innovation. Anthem Press.

24. Mazzucato, M., \& Perez, C. (2014). Innovation as Growth Policy: The Challenge for Europe (SPRU Working Paper Series. No 13). Science Policy Research Unit, University of Sussex Business School. Retrieved from https://www.sussex. ac.uk/webteam/gateway/file. php?name=2014-13-swps-mazzucato-perez.pdf\&site $=25$

25. Nelson, R. R., \& Winter, S. G. (1984). An Evolutionary Theory of Economic Change. Cambridge, Massachusetts, London, England: The Belknap Press of Harvard University Press.

26. NIFU. (2019). FoU-statistikk $i$ Norge - alle sektorer. (In Norwegian). Retrieved from https:// www.nifu.no/fou-statistiske/foustatistikk/hovedtall/

27. OECD. (2015). Guidelines for Collecting and Reporting Data on Research and Experimental Development. Retrieved from https:// www.oecd.org/sti/inno/Frascati2015-Glossary.pdf

28. OECD. (2016). Peer review of the German shipbuilding industry. Retrieved from https://www.oecd. org/sti/ind/PeerReview_Shipbuilding_Germany_FINAL.pdf

29. OECD. (2016). The Ocean Economy in 2030. Retrieved from http://www.oecd.org/sti/ futures/the-ocean-economy-in2030-9789264251724-en.htm

30. OECD. (2017). Peer review of the Norwegian shipbuilding industry. Retrieved from https://www.oecd. org/sti/ind/PeerReviewNorway_ FINAL.pdf 
31. OECD. (2021). RઐD expenditures by industry. Retrieved from https://stats.oecd.org/Index. aspx ?DataSetCode=STANI4_2020

32. Pece, A., Oros, O., \& Salisteanu, F. (2015). Innovation and economic growth: An empirical analysis for CEE countries. Procedia Econom$i c s$ and Finance, 26, 461-467. https://doi.org/10.1016/S22125671(15)00874-6

33. Regjering. (2019). Grønnere og smartere - morgendagens maritime noering (Report Meld. St. 10 (2020-2021)). (In Norwegian). Retrieved from https://www. regjeringen.no/no/dokumenter/ meld.-st.-10-20202021/id2788786/

34. Schumpeter, J. A. (1934). The Theory of Economic Development. Harvard University Press.

35. Schumpeter, J. A. (1942). Capitalism, Socialism and Democracy ( $3^{\text {rd }}$ ed.). New York: Harper Torchbooks.
36. Solow, R. M. (1956). A contribution to the theory of economic growth. The quarterly journal of economics, 70(1), 65-94. https:// doi.org/10.2307/1884513

37. Statista. (2021). Largest shipbuilding nations based on gross tonnage. Retrieved from https://www. statista.com/statistics/263895/ shipbuilding-nations-worldwideby-cgt/

38. Statistics Norway. (2021a). Principal figures for enterprises, by industry (2010-2019). Retrieved from https://www.ssb.no/en/statbank/

39. Statistics Norway. (2021b). Research and development in the business enterprise sector. Retrieved from https://www.ssb. no/en/teknologi-og-innovasjon/ forskning-og-innovasjon-i-naeringslivet/statistikk/forskning-ogutvikling-i-naeringslivet

40. The Research Council of Norway. (2019). Science \& Technology Indicators for Norway 2019.
Retrieved from https://www. forskningsradet.no/contentassets/c13c9822d47542108d768dfb4a8479c4/

science-and-technology-indicators-for-norway-2019_20.12.19_ final.pdf

41. Tinbergen, J. (1942). De groei van den voorraad van eenige kapitaalgoederen in zes landen vanaf omstreeks 1870. Maandschrift van het CBS.

42. World Bank. (2021). Research and development expenditure (\% of GDP). Retrieved from https:// data.worldbank.org/indicator/ GB.XPD.RSDV.GD.ZS

43. Øvrebø, O. A. (2021, May 1). Det grønne skiftet: Hvordan finansiere den store oppskaleringen? Energi og Klima. (In Norwegian). Retrieved from https://energiogklima.no/nyhet/det-gronneskiftet-hvordan-finansiere-denstore-oppskaleringen/ 